\title{
Gaya Kepemimpinan Di Pondok Pesantren Modern Putri Al-Mawaddah 2 Desa Jiwut Kec. Nglegok, Kab. Blitar
}

\author{
Khusumawati, ${ }^{1}$ Yasin Nurfalah ${ }^{2}$ \\ 1 Pascasarjana Institut Agama Islam Tribakti Kediri, 2Institut Agama Islam Tribakti Kediri \\ 1khusumastuti1@gmail.com,2yasinfalach23@gmail.com
}

\begin{abstract}
This research is framed by a large topic of leadership. More specifically this research is directed to analyze the tendency of leadership style in Islamic educational institutions. The subject is Putri Al Mawaddah Islamic Boarding School 2, Jiwut Village, Nglegok District, Blitar Regency, East Java. This study uses a descriptive qualitative approach. The focus of this research is about: 1) the tendency of leadership style, and 2) several aspects that contribute positively to the practice of leadership style. The research data was collected through interview, observation, documentation, and questionnaire techniques. While the analysis of the data follows the direction of Miles and Huberman which includes steps: 1) Data reduction, 2) Data display and 3) Conclusions. The results of this study concluded that: 1) The tendency of the leadership style at Putri Al Mawaddah Islamic Boarding School 2, Jiwut, Nglegok, Blitar Regency. the most dominant is democratic leadership; and 2) Some aspects that contribute to the practice of leadership style at the Putri Al Mawaddah Islamic Boarding School 2, Jiwut, Nglegok, Blitar Regency include: a) hereditary aspects; b) geographical; c) economy; d) aspects of the target vision and mission; and e) characteristics and advantages of boarding schools.
\end{abstract}

Keywords: Leadership Style, Modern Islamic Boarding School

\begin{abstract}
Abstrak
Penelitian ini dibingkai oleh topik besar kepemimpinan. Lebih spesifik penelitian ini diarahkan untuk menganalisis kecenderungan gaya kepemimpinan di lembaga pendidikan Islam. Subyeknya Pondok Pesantren Putri Al Mawaddah 2 Desa Jiwut, Kecamatan Nglegok, Kabupaten Blitar Jawa Timur. Penelitian ini menggunakan pendekatan kualitatif diskriptif. Fokus penelitian ini mendalami tentang: 1) kecenderungan gaya kepemimpinan, dan 2) beberapa aspek yang berkontribusi positif pada praktik gaya kepemimpinan tersebut. Data penelitian ini dikumpulkan melalui teknik wawancara, observasi, dokumentasi, dan angket. Sedangkan analisis datanya mengikuti arahan Miles dan Huberman yakni meliputi langkah: 1) Reduksi data, 2) Display data dan 3) Konklusi. Hasil penelitian ini menyimpulkan bahwa: 1) Kecenderungan gaya kepemimpinan di Pondok Pesantren Putri Al Mawaddah 2, Jiwut, Nglegok, Kabupaten Blitar. yang paling dominan adalah kepemimpinan demokratis; dan 2) Beberapa aspek yang berkontribusi dalam
\end{abstract}


praktik gaya kepemimpinan di Pondok Pesantren Putri Al Mawaddah 2, Jiwut, Nglegok, Kabupaten Blitar antara lain adalah : a) aspek keturunan; b) geografis; c) ekonomi; d) aspek target visi dan misi; serta e) ciri khas dan keunggulan pondok pesantren.

\section{Kata Kunci: Gaya Kepemimpinan, Pondok Pesantren Modern}

\section{Pendahuluan}

Berbicara mengenai pondok pesantren, tentu tidak lepas dari sejarah pondok pesantren itu sendiri yang merupakan lembaga pendidikan yang sudah ada sejak zaman dulu. Terdapat dua fungsi pondok pesantren dalam pendidikan nasional yaitu; pertama sebagai pelestari dan melanjutkan pendidikan rakyat, dan kedua mengubah sistem pendidikan aristokratis kedalam sistem pendidikan demokratis. ${ }^{1}$

Misi pendidikan Islam dalam hal ini pondok pesantren haruslah mampu mewujudkan nilai-nilai ke-Islam-an di dalam pembentukan manusia Indonesia, yang dalam abad 21 ini akan bertemu antara tuntutan intelek dan tuntutan agama sehingga pendidikan Islam mampu menjadi pendidikan alternatif dikalangan masyarakat Indonesia secara umum.

Sebagai upaya untuk mewujudkan misi pendidikan Islam di atas, pesantren dituntut untuk mampu bertahan dengan perkembangan zaman dan harus segera menghindari pandangan negatif, seperti halnya pesantren adalah lembaga pendidikan ortodoks, dan anti modern. Selain gambaran negatif di atas,

1 Jalaluddin. Kapita Selekta Pendidikan. (Jakarta: Kalam Mulia, 1990), h.21

Tengah Arus Mutu Pendidikan Menjawab pesantren juga merupakan lembaga yang mendapat stigma positif dari masyarakat. Stigma positif yang selama ini disandang oleh pesantren adalah pesantren merupakan lembaga yang mempunyai 4 karakter seperti ikhlas, mandiri, penuh dengan perjuangan dan heroik, tabah serta selalu mendahulukan kepentingan masyarakat sekitarnya. ${ }^{2}$

Abad ke-21 membawa perubahan era yang populer dengan sebutan era globalisasi. Dampak globalisasi yang terjadi saat ini membawa masyarakat Indonesia melupakan pendidikan karakter bangsa. Pendidikan karakter bangsa merupakan fundasi bagi suatu bangsa dalam upaya membantu perkembangan jiwa anak-anak baik lahir maupun batin

Sejarah telah berhasil menggoreskan lukisan lukisan indah pada dunia pendidikan,untuk mencetak kader kader pejuang bangsa yang memiliki moral,semangat juang yang tinggi,hanya mereka yang bisa unggul untuk melebarkan sayapnya,pesantren putri Almawaddah tidak akan tertinggal akan hal itu. Adanya hubungan yang terjalin dengan baik antara keluarga besar Almawaddah dengan wali santriwati

Problematika Kontemporer Manajemen Mutu Pesantren. (Semarang: Rasail Media Group, 2011), h. 67 
merupakan bukti nyata bahwa lembaga ini mempunyai komitmen, tidak hanya berkiprah dalam dunia pendidkan akan tetapi mampu mempersatukan umat

Jadi dapat diambil kesimpulan bahwa dalam rangka memperbaiki pendidikan di Indonesia terkait pendidikan karakter, Pondok Pesantren merupakan lembaga pendidikan Islam yang sudah mempunyai kerakter tersendiri seperti religuis, ikhlas, mandiri, penuh dengan perjuangan dan heroik, tabah serta selalu mendahulukan kepentingan masyarakat sekitarnya, dan lain-lain. Akan tetapi beberapa stigma negatif muncul terkait pesantren merupakan lembaga yang archaic atau ortodok dan bahkan anti dengan dunia modern.

Selain itu, dalam konteks kepemimpinan, pesantren cenderung menggunakan kepemimpinan otoriterpaternalistik dan cenderung rendah perhatiannya pada hasil sekaligus rendah perhatiannya pada kekompakan anggota. Sehingga secara rasional perilaku kepemimpinan ini sangat kurang efektif. ${ }^{3}$

Melihat pentingnya pembaharuan dalam dunia pesantren terkait dengan manajemen pendidikan pesantren, penulis tertarik melakukan penelitian tentang bagaimana pola kepemimpinan Pondok Pesantren Modern Putri Al Mawaddah 2 Jiwut Nglegok Blitar, Pesantren dalam usia yang sudah dapat di kategorikan dewasa ini. Pendidikan dan pengajaran di Pondok Pesantren
Modern Putri Al Mawaddah 2 selalu berusaha meningkatkan kualitasnya dengan berbagai cara dan upaya untuk mencapai tujuan yang telah ditetapkan.

Dalam penyelenggaraan pendidikan, Pondok Pesantren Modern Putri Al Mawaddah 2 mengikuti peraturan perundang undangan sistem pendidikan nasional yang telah di tetapkan oleh pemerintah. Di samping mendasari dengan ketentuan Undang-Undang No. 20 Tahun 2003 tentang Sistem Pendidikan Nasional Pondok Pesantren Al Mawaddah 2 ini mengintegrasikannya juga dengan model pembelajaran dalam sistem pendidikan yang dilaksanakan oleh Pondok Pesantren Modern Gontor. Integrasi dua sistem pendidikan inilah yang kemudian menghasilkan praktek pendidikan yang cenderung memerlukan kepemimpinan yang efektif agar tujuan pendidikan dapat dicapai.

Terkait dengan tuntutan kepemimpinan yang efektif itulah maka peneliti tertarik untuk melakukan penelitian dalam bingkai ikhwal kepemimpinan. Lebih khusus penelitian ini ingin melihat kecenderungan gaya kepemimpian yang berjalan di pondok pesantren termaksud. Karenanya, maka peneliti menetapkan judul penelitian Analisis Kecenderungan Gaya Kepemimpinan di Pondok Pesantren Al Mawaddah 2 Desa Jiwut, Kecamatan Ngegok, Kabupaten Blitar. Dengan demikian maka fokus penelitian ini ditetapkan untuk menganalisis kecenderungan gaya kepemimpinan dan

3 Zaenal Arifin, Efektifitas Kepemimpinan Lembaga Pendidikan Islam di Pesantren. Jurnal Pemikiran Keislaman, 27(1), $40 \sim 64$. 
pada sejumlah aspek yang berkontribusi pada gaya kepemimpinan tersebut.

\section{Metode}

Penelitian ini merupakan penelitian kualitaif yaitu lebih menekankan realitas sosial sebagai sesuatu yang utuh, kelompok, dinamis, dan bersifat interaktif, untuk meneliti kondisi obyektif yang alamiah. Data yang diperoleh dapat berbentuk kata, gambar, kalimat, skema atau gambar. ${ }^{4}$

Oleh karena itu penggunaan pendekatan kualitatif dalam penelitian ini adalah dengan mencocokkan antara realita empirik dengan teori yang berlaku dengan menggunakkan metode diskriptif. Pendekatan yang dilakukan dalam penelitian ini adalah pendekatan fenomenologis. Pendekatan fenomenologis secara konseptual adalah sebuah studi penampakan dalam obyek, peristiwa, atau kondisi dalam persepsi individu. ${ }^{5}$ Teori ini digunakan untuk penelitian gaya kepemimpinan yang diterapkan di Pondok Pesantren Modern Putri Al Mawadah 2 Desa Jiwut, Kecamatan Nglegok, Kabupaten Blitar

Lokasi yang menjaadi obyek penelitian adalah Pondok Pesantren Modern Putri Al Mawadah 2 Desa Jiwut, Kecamatan Nglegok, Kabupaten Blitar.

Untuk menentukan data yang akan dipergunakan, maka dibutuhkan teknik pengumpulan data agar bukti-bukti dan fakta-fakta yang diperoleh berfungsi sebagai data objektif. Adapaun metode pengumpulan data yang digunakan dalam penelitian ini ada tiga yakni: observasi (observation), wawancara (interview), dan dokumentasi (dokumentation).

\section{Hasil dan Pembahasan \\ Konsep Kepemimpinan}

Kepemimpinan merupakan salah satu topik yang selalu menarik untuk dikaji dan diteliti, karena paling banyak diamati dan sekaligus fenomena yang paling sedikit dipahami. Aktivitas dan hubungan di dalam kelompok atau terlihat kesamaannya. Definisi berbeda dalam berbagai hal, termasuk siapa yang bisa menanamkan pengaruhnya, maksud tujuan dari pengaruh itu, cara menanamkan pengaruh, dan hasil pengaruh itu sendiri. Inilah dasar konsep pemimpinan.

Pada hakikatnya kepemimpinan di pesantren merupakan kepemimpinan yang berkepribadian dan memiliki ciri utama kekarismatikan. Watak karismatik timbul karena kedalaman ilmu dan kemauan menguasai segala permasalahan yang ada, baik dipesantren maupun dilingkungan masyarakat sekitar. Dalam perjalanan waktu, kepemimpinan pun mengalami perkembangan.

Sejatinya, pandangan dasar dari kepemimpinan adalah adanya faktor lain yang ikut mempengaruhi efektifitas kepemimpinan. Tidak saja karena kecenderungan perilaku itu yang mempengaruhi sesuatu gaya kepemimpi-

5 Turnomo Raharjo, Menghargai Perbedaan Kultur, (Yogyakarta: Pustaka Pelajar, 2005). h.2 
nan. Tetapi satu variable lagi yang sangat penting tidak boleh lalai diperhatikan yaitu variable situasi. Variable situasi dalam kaitan ini adalah kematangan anggota kelompok. Kematangan (maturity) diukur dari unsur kemampuan dan unsur kemauan. Kemampuan yang tinggi dipadu dengan kemampuan dengan kemauan yang juga sangat tinggi, dalam kaitan ini dinilai sebagai tingkat kematangan yang sangat tinggi. Kemampuan rendah dan kemauan yang juga yang sangat rendah akan mengindikasikan tingkat kematangan yang sangat rendah. Dalam kepemimpinan, argumen utamanya adalah, tidak ada kepemimpinan yang berhasil sepanjang kepemimpinan itu tidak menyertakan situasi anggota kelompok sebagai variable pengalaman dan usaha pendidikan; juga sesuai dengan tuntutan ekologisnya.

\section{Jenis Gaya Kepemimpinan}

Berikut ini disajikan beberapa model kepemimpinan. Penelitian lebih lanjut menunjukan bahwa perilaku kepemimpinan cenderung berbeda-beda dari situasi ke situasi lain. Dalam kepemimpinan, pemimpin harus mampu melaksanakan diagnosis dengan baik terhadap situasi yang ada, sehingga pemimpin harus mampu:

1. Mengubah-ubah perilaku sesuai dengan situasi dan kondisinya.

2. Memperlakukan bawahan sesuai dengan tingkat kematangannya yang berbeda-beda.
Berbagai study tentang macammacam kepemimpinan ada 5 varian gaya kepemimpinan menurut Suko Susilo, ${ }^{6}$ yaitu

1. Gaya Kepemimpinan Laissez faire

Gaya kepemimpinan laissez faire (bebas lepas) ini memberi penjelasan bahwa adanya derajat atau intensitas perlaku kepemimpinan yang sangat rendah untuk dua kecenderungan sekaligus. Pemimpin rendah perhatiannya kepada usaha pembinaan kompakkan kelompok sekaligus memiliki perhatian yang sangat rendah pada penyelesaian tugas-tugas kelompok.

2. Otoriter

Kepemimpinan otoriter mendasarkan diri pada kekuasaan yang bersumber pada keterpaksaan dan rasa takut orangorang yang dipimpin.Pemimpin sealu ingin berperan sebagai pemain tunggal dengan menguasai situasi melalui penekanan tindakan yang hanya berorientasi kepada penyelesaian tugastugas kelompok. Setiap keputusan di tetapkan tanpa partisipasi bawahan. Bawahan tidak pernah di beri informasi yang mendetail mengenai rencana dan tindakan yang harus di lakukan.Semua ganjaran dan hukuman terhadap bawahan di berikan atas pertimbangan pribadi pemimpin.

3. Demokratis

Kepemimpinan demokratis memiliki kecenderungan perilaku yang sangat memprihatinkan hubungan-hubungan personal yang dapat membimbing 
kekompakan dengan di barengi mendorong bawahan untuk bekerja lebih perhatian perhatian yang tinggi terhadap baik.

produktivitas kelomok. Kekuatan kepemimpinan ini bukan terletak pada person atau individu pemimpin,tetapi justru terletak partisipasi aktif dari setiap anggota kelompok yang meliputi pemimpin dan yang dipimpin.

\section{Kekeluargaan}

Gaya kepemimpinan kekeluargaan ini seringkali diidentifikasi sebagai country club leadership style. Fokus perilaku kepemimpinan ini adalah bahwa anggota kelompok yang di pimpin,dengan segenap harapan dengan kebutuhannya sangat di perhatikan serta pemimpin mau dengan senang hati mendengar suara bawahan.

5. Jalan Tengah

Seorang pemimpin dengan gaya kepemimpinan jalan tengah memiliki pemikiran sedang-sedang saja untuk kecenderungan orientasi yang memperhatikan kekompakkan kelompok dan perhatiannya pada penyelesaian tugas atau produktivitas kelompok.Dia mencoba menciptakan hubungan pribadi dan membina moral orang-orang yang bekerja dalam kelompok yang di pimpinnya,dan memperhatikan struktur inisiasi dalam pencapaian tugas secara memadai serta tidak terlampau mencolok.Pemipin bergaya jalan tengah ini dalam aktifitas kepemimpinannya tidak menciptakan target tugas terlampau tinggi sehingga menyulitkan pencapaian serta berbaik untuk

\section{Kecenderungan Perilaku Pemimpin} Pondok Pesantren Al Mawaddah

a. Pengambilan Keputusan

Kyai/Bu Nyai memang satusatunya yang jadi pemantau bagi santrisantrinya, beliau memimpin dengan disiplin tinggi tetapi tepap mempertimbangkan segala sesuatu untuk mempertahankan keberadaan santri agar dapat menuntut ilmu dengan baik. Beliau selalu menata dan memberi pengarahan terhadap pendidikan dan kedisiplinan santrinya.

Yang paling tampak berdasarkan pengamatan peneliti adalah tindakan yang sangat jarang dilakukan sendiri. Dalam banyak hal $\mathrm{Bu}$ Nyai sering mengikut sertakan para pengurus dalam setiap tindakannya. Bahkan tidak sekedar tindakan, tetapi proses pengambilan keputusan sebelum bertindakpun beliau terkesan merasa seperti kurang tepat. Untuk sejumlah hal yang penting maupun sebaliknya beliau hampir selalu mengajak orang lain berdiskusi terlebih dahulu.

\section{b. Orientasi perilaku}

Sosok Bu Nyai muda memang berbeda Kyai sepuh, dalam memimpin sangat santun dan bijaksana. Beliau dilahirkan di Ponorogo pada tanggal 22 Agustus 1975, beliau sangat kental dengan bahasa khas Ponorogo. Beliau lebih cenderung pada kedisiplinan namun tidak selalu keras, kesabarannya selalu di tonjolkan dalam setiap situasi, terhadap keluarga dan familinya selalu 
mengedepankan kebersamaan karena letak rumah keluarga sangat berdekatan satu lokasi dengan pondok pesantren.

Berdasarkan pengamatan peneliti, beliau sosok panutan karena penuh dengan kewibawaan, kesabaran, kedisiplinan. Dan beliau mendukung, memberi pengarahan terhadap programprogram pengurus pondok karena selalu pengurus berkonsultasi kepada beliau, sejauh program itu tidak bertentangan denga syara'. Bahkan ketika memutuskan tentang syahriyah yang inginnya pengurus di tambah namun selama masih cukup untuk kebutuhan operasional tidak boleh ditambah, alasan beliau tidak ingin memberatkan wali murid atau masyarakat.

c. Sumber Kekuasaan

Kepemimpinan Ibu Nyai juga ikut mempengaruhi keberadaan pondok pesantren, kita tahu bahwa Bu Nyai biasanya menjadi pemikiran dan pertimbangan pertama ketika wali santri akan menempatkan anaknya di suatu pondok pesantren. Seseorang yang paling menonjol sekaligus yang berperan penting dalam kesuksesannya memimpin lembaga yang dipimpinnya adalah pemimpinnya.

Seseorang sukses menjadi pemimpin pondok pesantren bisa jadi bukan saja karena strategi yang di gunakan, tetapi juga ciri atau sifatnya yang menonjol dari dalam diri pribadinya. Setiap organisasi apapun jenisnya pasti memiliki seorang pemimpin yang harus menjalankan kepemimpinan dan menejemen bagi keseluruhan organisasi sebagai satu kesatuan yang tidak bisa di pisahkan. Demikian juga halnya dengan lembaga pendidikan, sangat membutuhkan pemimpin yang loyal dan mempunyai visi misi, ide dan strategi untuk mengembangkan lembaga pendidikan.

Dalam menata pesanteren $\mathrm{Bu}$ Nyai banyak menggunakan metode yang beragam, kadang beliau yang dapat saya tangkap ketika menata dan mengarahkan tentang bangunan menggunakan direktif di karenakan yayasan berperan penuh atas keadaan bangunan, jikalau yayasan mendapat kan sumbangan bantuan, itu semua di serahkan ke pimpinan yayasan (Bu Nyai) karena bila ada kekurangan dana bangunan dapat di selesaikan oleh yayasan (Bu Nyai).

Juga kadang mengguanakan tipe kunsultatif ketika memutuskan atau mendiskusikan tentang awal tahun pelajaran dengan lembaga-lembaga yang terkait. Dalam hal rapat rutin tri wulan dengan lembaga sering memunculkan sifat partisipatif, ketika lembaga memaparkan programnya untuk menyelaraskan lembaga satu dengan yang lainnya.

Diantara pendukung dalam pembangunan fisik dan mental ini menimbulkan kekarismaan tersendiri yakni ditinjau dari pendidikan, kepemimpinan Ibu Nyai termasuk harus tinggi berpengalaman di bidang kenegaraan, social budaya, kemanusiaan dan juga memiliki hubungan luas, tidak hanya masyarakat dan pejabat local, tetapi juga membangun hubungan dengan tokoh- 
tokoh dan pejabat nasional dan internasional.

\section{Analisis Kecenderungan Gaya Kepemimpinan di PP Almawaddah 2}

Kepemimpinan Ibu Nyai yang demokratis dan dilaksanakan secara kolektif dengan manajemen dan administrasi yang teratur merupakan ciri relatif yang berbeda dengan pesantren lainnya yang biasanya otoriter dengan penguasa tunggal yaitu kyai dan manajemen serta administrasi yang tidak tertata rapi. Dalam hal ini Ibu Nyai telah memberikan warna baru bagi dunia pesantren yaitu warna kepemimpinan perempuan.

Bahwa dengan adanya perempuan menjadi pemimpin di pesantren, bukan merupakan sebuah kemunduran akan tetapi justru mampu menampilkan demokrasi, keteraturan dalam pendidikan dan kemajuan perekonomian, meskipun bisa di katakan masihjauh dari kesempurnaan dan perlu perjuangan panjang dalam menata pesantren serta memperjuangkan perempuan untuk menjadi pemimpin pesantren. Perempuan juga mampu berkiprah di masyarakat, baik di organisasi sosial bahkan di organisasi politik dari tingkat dari tingkat desa sampai tingkat nasional, asal memiliki kemampuan dan mendapatkan dukungan dari masyarakat.

Dari deskripsi dalam penelitian ini telah menunjukkan tampilnya seorang perempuan sebagai Ibu Nyai yang menguasai ilmu agama dengan berbagai literatur, Klasiknya,shalihah dan dari keturun kyai yang bereputasi baik, memilki jumlah murid, memiliki ysng banyak serta telah mendapatkan pengakuan dan telah memenuhi kriteria seorang pemimpin pesantren yang dikemukakan oleh Steenbrink, fenomena yang sangat langka di dunia Islam terutama di Indonesia.

Secara umum Ibu Nyai juga telah memiliki 4 sifat kepemimpinan yang di rumuskan oleh Keith Davis di mana Ibu Nyai selain memiliki kecerdasan, kedewasaan dan keluasan hubungan sosial,motivasi diri dan dorongan berprestasi di mana beliau tidak berhenti menuntut ilmu sampai saat ini di samping itu beliau juga memiliki sifat humanis dalam pergaulannya.

Secara singkat dapatlah dikatakan bahwa, dalam konteks pengambilan keputusan $\mathrm{Bu}$ Nyai memiliki kecenderungan gaya kepemimpinan kekeluargaan. Dikatakan demikian karena beliau selalu menyertakan atau mengikutsertakan orang yang dipimpin dalam proses pengambilan keputusan. Perilaku kepemimpinan yang demikian ini memiliki efek psikologis yang mendekatkan pemimpin dengan orang yang dipimpinnya. Kekompakkan dalam pondok pesantren dengan demikian terjamin dengan baik karena perilaku yang memang berkecenderungan menghasilkan kedekatan pemimpin dengan yang dipimpin ini.

Dari perspektif pemanfaatan sumber kekuasaan, pemimpin pondok $\mathrm{Al}$ Mawaddah yang sebenarnya memiliki beberapa kekuatan pengaruh ini tidak selalu menggunakannya. Artinya adalah pemanfaatannya disesuaikan dengan 
kebutuhan. Sesuaii hasil observasi peneliti, pemimpin pesantren putri ini yang paling sering terlihat adalah bekerjanya referent power atau sumber kekuasaan referensi.

Bu Nyai seperti sadar atas kekuatan atau daya pengaruh yang dimilikinya. Bukan hanya sebagai pemimpin pondok tetapi lebih karena dia sebagai anak pendiri pondok. Terutama dalam kultur nahdliyin, jamaah atau santri lebih memandang keturunan kyai sebagai sumber kekuatan pengaruh yang akan menghasilkan kepatuhan sukarela. Bukan expert power atau sumber kekuasaan keahlian, tetapi justru karisma seorang pemimpin lebih muncul karena faktor hereditas (keturunan).

Jadi dengan demikian, mengikuti arahan teori Gaya Kepemimpinannya Paul Hersey dan Kenneth Blanchard maka kecenderungan gaya kepemimpinan di Pondok Pesantren Al Mawaddah sebenarnya condong ke demokratis. Gaya kepemimpinan demokratis di pondok pesantren putri ini memang tidak konstan atau tidak selalu berjalan konsisten tetapi dalam penelitian ini memang cukup terlihat jelas. Pada kesempatan atau konteks pendisiplinan santri untuk penghargaannya pada waktu memang Bu Nyai terlihat otoriter, namun kesan ini tidaklah dominan.

Gaya kepemimpinan yang demokratis merupakan gaya kepemimpinan yang di sukai oleh msyarakat sebagaimana hasil penelitian dari Kurt Lewin Ronald Lippitt dan Ralp K White Tetapi sebenarnya untuk masyarakat politik seperti halnya pada oragnisasi politik. Suatu pengecualian jika ternyata berdasarkan penelitian ini justru di pondok pesantren putri gaya kepemimpinan demokratis ini berlangsung.

\section{Kesimpulan}

Berdasarkan hasil penelitian sebagaimana telah diuraikan pada beberapa bab sebelum ini, maka uraian singkat berikut merupakan kesimpulan peneliti.

1. Menganalisis praktik pengambilan keputusan, perilaku kepemimpinan, dan pemanfaatan sumber kekuasaan, maka dapat disimpulkan bahwa gaya kepemimpinan demokratis menjadi yang paling dominan yang tampak dalam kepemimpinan di Pondok Pesantren Putri Al Mawaddah, Jiwut, Nglegok, Kabupaten Blitar.

2. Beberapa aspek yang berkontribusi dalam praktek gaya kepemimpinan demokratis di Pondok Pesantren Putri Al Mawaddah Jiwut, Nglegok Kabupaten Blitar antara lain : a) aspek keturunan; b) geografis; c) ekonomi; d) aspek target visi dan misi; serta e) ciri dan keunggulan pondok pesantren.

\section{Daftar Pustaka}

Arifin, Z. (2016). Efektifitas Kepemimpinan Lembaga Pendidikan Islam di Pesantren. Jurnal Pemikiran Keislaman, 27(1), $40 \sim 64$.

Arikunto, S, Prosedur Penelitian Suatu Pendekatan Praktik, Jakarta: Rineka Cipta, 2010 
Azzat. M. A, (2014), Mengembangkan Kecerdasan Spiritual bagi Anak, Jakarta: Ar-Ruzz Media.

Bukhari, Abu Abd Allah Muhammad Ibn Ismail Al, (1987) Sahih al-Bukhari, Beirut: Dar al-Qalam.

Jalaluddin. (1990). Kapita Selekta Pendidikan. Jakarta: Kalam Mulia. Kartono

Jalal, Abd al-Fattah, (1988) Asas alTarbiyat al-Islam, Diterjemahkan oleh Henry Noer Ali dengan judul AzasAzas Pendidikan Islam Bandung: Diponegoro.

Mustofa Al Ustadz (2019) Warta Almawaddah.Edisi 1440 H/2019 M. Jetis Ponorogo, Jawa Timur.

Mulyassa, E. (2014). Manajemen Pendidikan Karakter. Jakarta: Bumi Aksara.

Noor. J, (2012), Metode Penelitian, Jakarta: Prenadamedia Group

Nurihsan, Syamsu, (2010), Landasan Bimbingan dan Konseling, Bandung: PT Remaja Rosdakarya.

Purwanto, (2012), Metodologi Penelitian Kuantitatif untuk Psikologi dan Pendidikan, Yogyakarta: Pustaka Belajar.

Sa' dulloh, (2008), 9 Cara Praktis Menghafal Al Qur'an, Jakarta: Gema Insani 2008.

Sanjaya, Wina, (2010), Perencanaan dan Desain Sistem Pembelajaran, Jakarta: Kencana.

Siregar. S, (2013), Metode Penelitian Kuantitatif. Jakarta: Prenadamedia Group.
Subagyo. J. S, (2004), Metode Penelitian dalam Teori dan Praktik, Jakarta: PT. Rineka Cipta

Subana, (2005), Statistika Pendidikan, Bandung: CV. Pustaka Setia.

Susilo, Suko, 2013, Dasar-Dasar Psikologi Sosial, Jenggala Pustaka Utama, Surabaya.

Susilo, Suko, 2008, Memahami Kepemimpinan, Surabaya, Jenggala Pustaka Utama

Umiarso dan Zazin, Nur. (2011). Pesantren di Tengah Arus Mutu Pendidikan Menjawab Problematika Kontemporer Manajemen Mutu Pesantren. Semarang: Rasail Media Group 